\title{
IAMJ
}

INTERNATIONAL

AYURVEDIC

MEDICAL JOURNAL

\section{EFFECT OF VASAGUDUCHCHADI KASAYAM IN A CASE OF HYPERLIPIDAEMIA -} A CASE STUDY

\section{Durbadal Majumdar ${ }^{1}$, Phalguni Bhattacharya ${ }^{2}$, Suman Kundu ${ }^{3}$}

${ }^{1}$ Assistant Professor, Dept. of Shalyatantra, Raghunath Ayurved Mahavidyalaya \& Hospital, Contai, Purba Medinipur, West Bengal, India

${ }^{2}$ Assistant Professor, Dept. of Kaumarbhritta, Raghunath Ayurved Mahavidyalaya \& Hospital, Contai, Purba Medinipur, West Bengal, India

${ }^{3}$ Associate Professor, Dept. of Kayachikitsa, Raghunath Ayurved Mahavidyalaya \& Hospital, Contai, Purba Medinipur, West Bengal, India

Corresponding Author: drdurbadalmajumdar@gmail.com

\section{https://doi.org/10.46607/iamj5109082021}

(Published Online: August 2021)

\section{Open Access}

(C) International Ayurvedic Medical Journal, India 2021

Article Received: 31/07//2021 - Peer Reviewed: 13/08/2021 - Accepted for Publication: 14/08/2021

\section{Check for updates}

\section{ABSTRACT \\ Vasa-Guduchchadi Kasayam is a widely used drug in Ayurveda. As per Ayurvedic literature 'Sahasrayoga', Vasa- guduchchadi Kasayam is a water decoction or water extract of a group of herbs, namely Vasaka, Guduchi, Triphala, Kutaki, Bhunimba, Nimba. It is mainly indicated in Pittaja Pandu. In this study, a lipid-lowering activi- ty of Vasa-guduchchadi Kasayam has been found in a case of hyperlipidaemia. Vasa-Guduchchadi Kasayam was prescribed as sole medication in that case not as co-therapy with any other conventional drug.}

Keywords: Vasaguduchchadi Kasayam, Hyperlipidaemia

\section{INTRODUCTION}

Disorders of lipid metabolism are one of the frequent pathological phenomena now a day in the population.
Lipid disorders play an important role in the pathogenesis of atherosclerosis and subsequent coronary 
artery diseases. ${ }^{1}$ Hyperlipidemia is defined as elevations of fasting total

cholesterol concentration which may or may not is associated with elevated TG

concentration. ${ }^{2}$ Lipid closely correlates with the concept of Meda in Ayurveda. Circulating lipid in the blood is known as Abaddha Meda in Ayurveda. ${ }^{3} \mathrm{Hy}-$ perlipidemia can broadly be classified as isolated elevation of cholesterol, isolated elevated TG and elevations of both. Hyperlipidemia

is originated from both primary secondary causes. An important secondary cause of high cholesterol is hypothyroidism. Other important contributors to secondary hyperlipidemia include diabetes, renal disease, alcoholism, poor lifestyle regimen. ${ }^{4}$ Diagnostic confirmation is achieved in hyperlipidaemia via serum fasting lipid profile, which routinely includes LDL, HDL, triglycerides, and total cholesterol. ${ }^{5}$ Lipid disorders may be considered as Medadusti in Ayurveda. Meda-Upashoshana and Srota Ksharatwa Utpadan are two significant pharmacological actions of Tikta Rasa that make it suitable to administer as a therapeutic agent in such conditions. ${ }^{6}$

\section{CASE REPORT}

The patient was male and having 41 years of age and residing at Contai, Purba Medinipur, West Bengal came to Kayachikitsa OPD of Raghunath Ayurved Mahavidyalaya \& Hospital on 13/08/20 with a chief complaint of disturbed sleep. The patient was nonhypertensive and non-diabetic till August 2020. The patient was found to be affected by hyperlipidaemia accidentally on a routine investigation.
The patient was healthy but got inadequate sleep both in respect to quality and duration.

Drug History: No history of regular medication.

Physical Examination: Vital sign at the time of 1st visit was as following -,

Blood Pressure - 124/84 mm of Hg, Pulse - 78 bpm, Respiratory Rate - 19/min, no abnormality was found in physical examination.

\section{Investigation:}

A routine examination of full blood count, lipid profile, fasting blood glucose which was advised on $13 / 08 / 20$ and done on $14 / 08 / 20$, was as following

Red cell count $-5.9 \times 10^{12} / \mathrm{cmm}$

Total leucocyte count $-6.2 \times 10^{9} / \mathrm{cmm}$

Neutrophils $-70 \%$

Lymphocyte - $26 \%$

Basophils - 1\%

Eosinophils - $1 \%$

Monocytes - 2\%

Fasting blood glucose - $89 \mathrm{mg} / \mathrm{dl}$,

Serum cholesterol - $274 \mathrm{mg} / \mathrm{dl}$

Serum triglyceride - $190 \mathrm{mg} / \mathrm{dl}$

LDL - $230 \mathrm{mg} / \mathrm{dl}$

HDL - $34 \mathrm{mg} / \mathrm{dl}$

The treatment advice to patients: Only Vasaguduchchadi Kasayam was advised to the patient orally at the dose of $25 \mathrm{ml}$ twice daily on empty stomach with normal water. Conventional hypolipidaemic drugs were advised.

Follow up: The patient was evaluated by biochemical markers of hyperlipidemia in a regular interval for more than three months and the following were the outcome.

\section{Present illness:}

\begin{tabular}{|l|l|l|l|l|}
\hline Date & Serum cholesterol & Serum triglyceride & LDL & HDL \\
\hline $14 / 08 / 2020$ & $274 \mathrm{mg} / \mathrm{dl}$ & $190 \mathrm{mg} / \mathrm{dl}$ & $230 \mathrm{mg} / \mathrm{dl}$ & $34 \mathrm{mg} / \mathrm{dl}$ \\
\hline $02 / 10 / 2020$ & $220 \mathrm{mg} / \mathrm{dl}$ & $150 \mathrm{mg} / \mathrm{dl}$ & $130 \mathrm{mg} / \mathrm{dl}$ & $42 \mathrm{mg} / \mathrm{dl}$ \\
\hline $17 / 11 / 2020$ & $190 \mathrm{mg} / \mathrm{dl}$ & $130 \mathrm{mg} / \mathrm{dl}$ & $94 \mathrm{mg} / \mathrm{dl}$ & $49 \mathrm{mg} / \mathrm{dl}$ \\
\hline
\end{tabular}

\section{DISCUSSION}

According to 'Sahasrayoga', Vasaguduchchadi Kasayam is a water decoction or water extract of several herbs including Vasaka, Guduchi, Triphala, Kutaki,
Bhunimba, Nimba. It it mainly indicated in Pandu, Raktapitta and Kamala. ${ }^{7}$ Vasaka, Guduchi, Kutaki, Bhunimba and Nimba are Tikta Rasa Pradhan Dravya. Guduchi is associated with a significant reduc- 
tion of serum and tissue cholesterol in alloxan diabetic rats. ${ }^{8}$ Similarly hypolipidemic effects have been shown in Triphala on the experimentally induced hypercholesteremic rats. ${ }^{9}$ Hypolipidaemic effect of Kutaki includes Low-density lipoprotein (LDL), triglyceride and total cholesterol levels are significantly reduced by Kutaki in high-fat diet treated mouse although serum HDL level seems not affected. ${ }^{10}$ Andrographolide and neoandrographolide are the diterpenoids from Bhunimba which are effective to reduce the levels of triglyceride, total cholesterol (TC) and low-density lipoprotein cholesterol in mice and rats. ${ }^{11}$ Neem has been shown protective effects against hyperlipidemia via improvement of the function of antioxidant markers and inhibition of oxidative damage of lipoproteins. ${ }^{12}$

\section{CONCLUSION}

In this case study, Vasaguduchchadi Kasayam has been found to alleviate the markers of hyperlipidaemia. Further extensive experimental and clinical research is essential to explore and establish its hypolipidemic effect.

\section{REFERENCES}

1. Keil U. Coronary artery disease: the role of lipids, hypertension and smoking. Basic Res Cardiol. 2000;95 Suppl 1:I52-I58. doi:10.1007/s003950070010

2. Nelson RH. Hyperlipidemia as a risk factor for cardiovascular disease. Prim Care. 2013;40(1):195-211. doi: 10.1016/j.pop.2012.11.003

3. Suman Kundu. A review on the concept of atisthoulya vis-a-vis metabolic syndrome: An approach to exploring the convectional entity. Int. J. Res. Ayurveda Pharm. 2018;9(5):35-40 http://dx.doi.org/10.7897/2277-4343.095151

4. Ballantyne CM, Grundy SM, Oberman A, et al. Hyperlipidemia: diagnostic and therapeutic perspectives. J Clin Endocrinol Metab. 2000;85(6):2089-2112. doi:10.1210/jcem.85.6.6642-1

5. Hill MF, Bordoni B. Hyperlipidemia. [Updated 2021 Feb 7]. In: StatPearls [Internet]. Treasure Island (FL): StatPearls Publishing; 2021 Jan-.

6. Agnivesha. Atreyabhadrakapiya Adhaya. In: Vaidya Acharya Jadavji Trikamji, editor. Charaka Saṃhita elaborated by Charaka and Dridhabala with Ayurveda-
Dipika Commentary by Chakrapaniidatta. 1st ed. Varanasi: Chaukhamba Orientalia; Reprinted 2015. p 145

7. K Nishteswar, R Vidyanath. Kasaya Prakaran. In: Sahasrayogam. 2nd ed. Varanasi: Chaukhamba Sanskrit Series Office; 2008. p 36

8. Stanely Mainzen Prince P, Menon VP, Gunasekaran G. Hypolipidaemic action of Tinospora cordifolia roots in alloxan diabetic rats. J Ethnopharmacol. 1999;64(1):53-57. doi:10.1016/s0378-8741(98)001068

9. Saravanan S, Srikumar R, Manikandan S, Jeya Parthasarathy N, Sheela Devi R. Hypolipidemic effect of Triphala in experimentally induced hypercholesteremic rats. Yakugaku Zasshi. 2007;127(2):385-388. doi:10.1248/yakushi.127.385

10. Lee HS, Yoo CB, Ku SK. Hypolipemic effect of water extracts of Picrorrhiza kurroa in high-fat diet treated mouse. Fitoterapia. 2006;77(7-8):579-584. doi:10.1016/j.fitote.2006.09.004

11. Yang T, Shi HX, Wang ZT, Wang CH. Hypolipidemic effects of andrographolide and neoandrographolide in mice and rats. Phytother Res. 2013;27(4):618-623. doi:10.1002/ptr.4771

12. Yarmohammadi F, Mehri S, Najafi N, Salar Amoli S, Hosseinzadeh $\mathrm{H}$. The protective effect of Azadirachta indica (neem) against metabolic syndrome: A review. Iran J Basic Med Sci. 2021;24(3):280-292. doi:10.22038/ijbms.2021.48965.11218

\section{Source of Support: Nil \\ Conflict of Interest: None Declared}

How to cite this URL: Durbadal Majumdar et al: Effect Of Vasaguduchchadi Kasayam In $\mathcal{A}$ Case of Hyperlipidaemia - $\mathcal{A}$ Case Study. International Ayurvedic Medical Journal \{online\} 2021 \{cited August 2021\} Available from: http://www.iamj.in/posts/images/upload/1917_1919.pdf 